\title{
Body mass index is not a predictor of biochemical recurrence after radical prostatectomy in Dutch men diagnosed with prostate cancer
}

\author{
Dieuwertje E. G. Kok • Joep G. H. van Roermund · Katja K. Aben • \\ Moniek W. M. van de Luijtgaarden · Herbert F. M. Karthaus • Oncko B. van Vierssen Trip • \\ Ellen Kampman · J. Alfred Witjes • Lambertus A. L. M. Kiemeney
}

Received: 9 July 2010 / Accepted: 26 November 2010 / Published online: 16 December 2010

(c) The Author(s) 2010. This article is published with open access at Springerlink.com

\begin{abstract}
Purpose To determine the effect of body mass index (BMI) on clinical and pathological characteristics at time of diagnosis and on risk of biochemical recurrence after radical prostatectomy among Dutch men diagnosed with prostate cancer.

Methods In total, 1,116 prostate cancer patients with known BMI, diagnosed between 2003 and 2006, were identified from the population-based cancer registry held by the Comprehensive Cancer Centre East, The Netherlands. Of
\end{abstract}

D. E. G. Kok · J. Alfred Witjes · L. A. L. M. Kiemeney ( $\square)$

Department of Urology,

Radboud University Nijmegen Medical Centre,

PO Box 9101, 6500 HB Nijmegen, The Netherlands

e-mail: b.kiemeney@ebh.umcn.nl

D. E. G. Kok · E. Kampman

Division of Human Nutrition, Wageningen University, PO Box 8129, 6700 EV Wageningen, The Netherlands

J. G. H. van Roermund

Department of Urology, Catharina Hospital,

PO Box 1350, 5602 ZA Eindhoven, The Netherlands

K. K. Aben · E. Kampman - L. A. L. M. Kiemeney

Department of Epidemiology, Biostatistics and HTA,

Radboud University Nijmegen Medical Centre,

PO Box 9101, 6500 HB Nijmegen, The Netherlands

K. K. Aben · M. W. M. van de Luijtgaarden - L. A. L. M. Kiemeney

Comprehensive Cancer Centre East,

PO Box 1281, 6501 BG Nijmegen, The Netherlands

H. F. M. Karthaus

Department of Urology, Canisius-Wilhelmina Hospital,

PO Box 9015, 6500 GS Nijmegen, The Netherlands

O. B. van Vierssen Trip

Department of Urology, Hospital Gelderse Vallei,

PO Box 9025, 6710 HN Ede, The Netherlands these, 504 patients underwent a radical prostatectomy. Patients were categorized as normal weight (BMI $<25 \mathrm{~kg} / \mathrm{m}^{2}$ ), overweight (BMI $25-30 \mathrm{~kg} / \mathrm{m}^{2}$ ), or obese (BMI $\geq$ $30 \mathrm{~kg} / \mathrm{m}^{2}$ ). Multivariable proportional hazards regression models, adjusted for age, prediagnostic PSA levels, and pathological characteristics were used to evaluate BMI as a prognostic factor for biochemical recurrence after radical prostatectomy.

Results Overall, clinical and biopsy characteristics did not significantly differ among BMI groups. Pathological characteristics after radical prostatectomy did not significantly differ among BMI groups, except for tumor stage, which was highest in obese patients $(P=0.017)$. For patients treated with radical prostatectomy, 5-year risk (95\% Confidence Intervals) of biochemical recurrence was 30\% (23$37 \%$ ) for normal weight, $32 \%$ (25-39\%) for overweight, and 25\% (9-41\%) for obese patients (log rank $P=0.810$ ). BMI was not an independent prognostic factor for biochemical recurrence in multivariable proportional hazards regression analyses (HR 0.99 per kg/m², 95\% CI: 0.93-1.06).

Conclusions Compared with non-obese men, pathological tumor stage tended to be higher in obese men. Clinical relevance of this finding is unclear, because BMI was not an independent predictor of biochemical recurrence after radical prostatectomy.

Keywords Obesity $\cdot$ Body mass index $\cdot$ Prostate cancer . Radical prostatectomy $\cdot$ Biochemical recurrence $\cdot$ Prognosis

\section{Introduction}

It has been hypothesized that obesity is a risk factor for the development and progression of prostate cancer (PC), although results are inconsistent. Most studies focusing on 
body size and PC were conducted in the United States, where a rapidly growing epidemic of obesity is reported with over $66 \%$ of adult Americans being overweight or obese [1]. In Europe, incidence of overweight and obesity is also increasing substantially [2]. Whether body size predisposes to adverse PC characteristics or outcome in European men is a matter of debate. Only few European studies examined effects of BMI on adverse pathological findings after biopsy or radical prostatectomy (RP) [3-6]. Gallina and colleagues suggested that high-grade PC at RP might be more prevalent among obese men; however, adding BMI to the multivariable model failed to increase predictive accuracy for high-grade PC [6]. Other studies did not find an association for BMI and tumor grade or stage, extracapsular extension, seminal vesicle invasion, lymph node involvement or positive surgical margins either [3-5]. Results for PC outcome are inconclusive as well. One study from Germany reported BMI as independent predictor of biochemical recurrence (BCR) after RP, although it did not improve predictive accuracy [7], while we and others did not find any effect of BMI on BCR rates after RP [5, 8] or brachytherapy [9].

Since results are conflicting and the epidemic of obesity is growing, additional evidence on the effects of body size on PC risk and prognosis in Europe are needed. Aim of the present study was to determine effects of BMI on clinical and pathological findings at time of diagnosis and on risk of BCR after RP among Dutch men with PC.

\section{Subjects and methods}

Patients diagnosed with PC were identified from the population-based cancer registry held by the Comprehensive Cancer Centre East (CCCE), The Netherlands. From 2003 to 2006, 1,668 patients with PC were identified in this region. Only patients with known BMI data were included in our analyses $(n=1,116)$. For all patients, clinical data were collected retrospectively by review of the clinical charts. Part of the patients $(n=951)$, who were diagnosed before the age of 76, participated in the POLYGENE project [10] and filled out a postal questionnaires as part of it. Self-reported weight and length were collected either from the POLYGENE questionnaire $(n=943)$ or from the clinical charts $(n=173)$ and were used to calculate BMI. For 278 patients, BMI was available from the questionnaire as well as from the charts (Spearman $r=0.81, P<0.001$ ). For these patients, BMI from the questionnaire was used in the analyses. BMI categories were defined according to the WHO criteria: BMI $<25 \mathrm{~kg} / \mathrm{m}^{2}$ (normal weight), BMI $25-$ $30 \mathrm{~kg} / \mathrm{m}^{2}$ (overweight), and BMI $\geq 30 \mathrm{~kg} / \mathrm{m}^{2}$ (obesity). The institutional review board approved the study, and all participants of the POLYGENE project provided written informed consent.
Primary treatments were categorized as radical prostatectomy (RP) with or without neoadjuvant androgen-deprivation therapy (ADT), radiotherapy (RT, including external beam radiation and brachytherapy) with or without ADT, active surveillance (AS), androgen-deprivation therapy (ADT), and others (such as cryotherapy and chemotherapy). In total, 517 patients who underwent RP as primary therapy were identified. Patients treated with neoadjuvant ADT $(n=13)$ were excluded, leaving 504 patients for analysis. BMI was evaluated as prognostic factor for BCR, which is defined as two consecutive PSA levels $\geq 0.2 \mathrm{ng} / \mathrm{ml}$. For these analyses, 11 patients were excluded, because data on post-operative PSA levels or BCR status were missing. After RP, patients were generally seen after 6 weeks, 3, 6, 9 , and 12 months and then every 6 months, according to the national guidelines for PC follow-up [11]. RP specimens were processed according to protocols from the institutes where patients were submitted to. Gleason grade was presented as the sum of two main Gleason scores. Clinical and pathological stages were classified according to the 2002 TNM classification based on the American Joint Committee on Cancer guidelines (AJCC) [12].

We used Kruskal-Wallis tests to assess the association between BMI categories and continuous clinical and pathological variables, while Chi-square tests were applied to categorical variables. Risk of BCR was calculated with the Kaplan-Meier method, using the log-rank test to compare BMI groups. Univariable and multivariable proportional hazards regression analyses adjusted for age, prediagnostic PSA levels, and pathological variables (Gleason score at $\mathrm{RP}$, pathological stage, surgical margin status, and lymph node status) were performed to evaluate whether BMI is a prognostic factor for BCR after RP. The significance level was set at $P<0.05$, and all $P$ values were two tailed. Statistical Package of Social Sciences (SPSS, version 16.0, Chicago, Illinois) was used for all analyses.

\section{Results}

Patient characteristics are shown in Table 1. Among all PC patients included in the analyses $(n=1,116)$, median age at diagnosis was 66.3 (inter-quartile range: $61.2-70.5$ ) years. Median BMI was 25.3 (IQR: 23.9-27.0) $\mathrm{kg} / \mathrm{m}^{2}$, with $47 \%$ of this population being overweight and $7 \%$ obese. Overall, no statistically significant differences for clinical or pathological findings were observed among the BMI groups. Although not statistically significant, obese patients were somewhat less likely to be referred for RP compared to normal weight and overweight patients (38\% versus $46 \%$ and $48 \%$, respectively).

Table 2 shows characteristics of patients with PC who underwent RP. Median age and BMI of patients treated 
Table 1 Demographic, clinical, and pathological characteristics of Dutch patients diagnosed with prostate cancer according to BMI categories

\begin{tabular}{|c|c|c|c|c|c|}
\hline & Total group & $\mathrm{BMI}<25 \mathrm{~kg} / \mathrm{m}^{2}$ & BMI $25-30 \mathrm{~kg} / \mathrm{m}^{2}$ & $\mathrm{BMI} \geq 30 \mathrm{~kg} / \mathrm{m}^{2}$ & $P$ value \\
\hline Number of patients (\%) & $1,116(100 \%)$ & $510(46 \%)$ & $530(47 \%)$ & $76(7 \%)$ & - \\
\hline Age at diagnosis (years) & $66.3(61.2-70.5)$ & $66.1(61.5-71.0)$ & $66.2(61.0-70.2)$ & $65.1(61.1-69.6)$ & 0.753 \\
\hline $\mathrm{BMI}\left(\mathrm{kg} / \mathrm{m}^{2}\right)$ & $25.3(23.9-27.0)$ & $23.7(22.9-24.4)$ & $26.6(25.8-27.8)$ & $31.6(30.7-33.6)$ & - \\
\hline BMI at age $18\left(\mathrm{~kg} / \mathrm{m}^{2}\right)^{\mathrm{a}}$ & $22.2(21.0-23.7)$ & $21.5(20.2-22.6)$ & $23.0(21.8-24.2)$ & $24.4(23.1-28.1)$ & - \\
\hline Height $(\mathrm{cm})$ & $177(172-182)$ & $178(173-183)$ & $176(172-180)$ & $175(172-179)$ & - \\
\hline Weight (kg) & $80(74-85)$ & $75(70-80)$ & $83(80-90)$ & $100(92-104)$ & - \\
\hline \multicolumn{6}{|l|}{ Smoking $(\%)$} \\
\hline Never & $170(15 \%)$ & $86(17 \%)$ & $74(14 \%)$ & $10(13 \%)$ & \multirow[t]{3}{*}{0.035} \\
\hline Former & $641(57 \%)$ & $285(56 \%)$ & $321(61 \%)$ & $35(46 \%)$ & \\
\hline Current & $136(12 \%)$ & $80(16 \%)$ & $50(9 \%)$ & $6(8 \%)$ & \\
\hline \multicolumn{6}{|l|}{ Family history of prostate cancer $(\%)$} \\
\hline Yes & $228(20 \%)$ & $101(20 \%)$ & $117(22 \%)$ & $10(13 \%)$ & \multirow[t]{2}{*}{0.285} \\
\hline No & $736(66 \%)$ & $357(70 \%)$ & $336(63 \%)$ & $43(57 \%)$ & \\
\hline Prediagnostic PSA level $(\mathrm{ng} / \mathrm{ml})^{\mathrm{b}}$ & $10(6-20)$ & $9(6-20)$ & $10(7-21)$ & $10(7-27)$ & 0.187 \\
\hline \multicolumn{6}{|l|}{ Gleason score biopsy (\%) } \\
\hline$<7$ & $689(62 \%)$ & $331(65 \%)$ & $316(60 \%)$ & $42(55 \%)$ & \multirow[t]{3}{*}{0.128} \\
\hline 7 & $226(20 \%)$ & $88(17 \%)$ & $120(23 \%)$ & $18(24 \%)$ & \\
\hline$>7$ & $120(11 \%)$ & $49(10 \%)$ & $61(12 \%)$ & $10(13 \%)$ & \\
\hline \multicolumn{6}{|l|}{ Clinical stage (cTNM) $(\%)$} \\
\hline $\mathrm{cT} 1$ & $447(40 \%)$ & $200(39 \%)$ & $224(42 \%)$ & $23(30 \%)$ & \multirow[t]{3}{*}{0.229} \\
\hline $\mathrm{cT} 2$ & $418(38 \%)$ & $196(38 \%)$ & $194(37 \%)$ & $28(37 \%)$ & \\
\hline $\mathrm{cT} 3$ or cT4 & $233(21 \%)$ & $107(21 \%)$ & $104(20 \%)$ & $22(29 \%)$ & \\
\hline \multicolumn{6}{|l|}{ Primary treatment $(\%)$} \\
\hline Active surveillance (AS) & $121(11 \%)$ & $58(11 \%)$ & $57(11 \%)$ & $6(8 \%)$ & \multirow[t]{7}{*}{0.585} \\
\hline RP without ADT & $504(45 \%)$ & $230(45 \%)$ & $245(46 \%)$ & $29(38 \%)$ & \\
\hline RP with ADT & $13(1 \%)$ & $4(1 \%)$ & $9(2 \%)$ & - & \\
\hline RT without ADT & $115(10 \%)$ & $60(12 \%)$ & $46(9 \%)$ & $9(12 \%)$ & \\
\hline RT with ADT & $210(19 \%)$ & $94(19 \%)$ & $100(18 \%)$ & $16(21 \%)$ & \\
\hline ADT & $138(12 \%)$ & $58(11 \%)$ & $66(12 \%)$ & $14(18 \%)$ & \\
\hline Others & $10(1 \%)$ & $5(1 \%)$ & $4(1 \%)$ & $1(1 \%)$ & \\
\hline
\end{tabular}

Data presented as median (IQR) or number $(\%)$

Percentages may not add up to $100 \%$ because of missing values

$A D T$ androgen-deprivation therapy, $A S$ active surveillance, $B M I$ body mass index, $c T N M$ clinical tumor-node-metastasis, $P S A$ prostate specific antigen, $R P$ radical prostatectomy, $R T$ radiotherapy

a Missing $n=243$

b Missing $n=12$

with RP were 63.3 (IQR: 58.8-67.1) years and 25.3 (IQR: 23.7-26.9) kg/m². Pathological characteristics after RP did not significantly differ between BMI groups, except for tumor (pT) stage which was somewhat higher in obese patients $(P=0.017)$. Furthermore, obese patients tended to have higher prediagnostic PSA levels compared to overweight and normal weight patients $(P=0.004)$. BMI presented as a continuous variable, however, was only weakly correlated with prediagnostic PSA levels (Spearman $r=0.13, P=0.004)$. Median follow-up of patients treated with RP was 40.3 (IQR: 19.5-53.1) months. In total, 142 patients developed BCR after RP. The 5-year risk (95\% CI) of BCR was $30 \%(23-37 \%), 32 \%(25-39 \%)$, and $25 \%$ (9-41\%) for normal weight, overweight, and obese patients, respectively ( $\log$ rank $P=0.810$ ) (Fig. 1).

As presented in Table 3, BMI was not a significant prognostic factor for BCR after RP in univariable (HR 1.02 per $\mathrm{kg} / \mathrm{m}^{2}, 95 \% \mathrm{CI}: 0.97-1.07$ ) or multivariable (HR 0.99 per $\mathrm{kg} / \mathrm{m}^{2}, 95 \%$ CI: $\left.0.93-1.06\right)$ analyses after adjustment for age, prediagnostic PSA, Gleason score at RP, positive surgical margins, positive lymph nodes, and pathological stage. Higher Gleason score, pathological stage, and positive 
Table 2 Demographic, clinical, and pathological characteristics of Dutch patients with prostate cancer treated with radical prostatectomy (RP)

\begin{tabular}{|c|c|c|c|c|c|}
\hline & Total group & $\mathrm{BMI}<25 \mathrm{~kg} / \mathrm{m}^{2}$ & BMI $25-30 \mathrm{~kg} / \mathrm{m}^{2}$ & $\mathrm{BMI} \geq 30 \mathrm{~kg} / \mathrm{m}^{2}$ & $P$ value \\
\hline Number of patients (\%) & $504(100 \%)$ & $230(46 \%)$ & $245(49 \%)$ & $29(6 \%)$ & - \\
\hline Age at RP (years) & $63.3(58.8-67.1)$ & $63.4(58.7-66.7)$ & $63.2(58.8-67.4)$ & $63.0(59.3-67.8)$ & 0.961 \\
\hline $\operatorname{BMI}\left(\mathrm{kg} / \mathrm{m}^{2}\right)$ & $25.3(23.7-26.9)$ & $23.7(22.9-24.4)$ & $26.6(25.8-27.7)$ & $31.3(30.5-34.3)$ & - \\
\hline Prediagnostic PSA $(\mathrm{ng} / \mathrm{ml})^{\mathrm{a}}$ & $8(6-12)$ & $7(5-10)$ & $8(6-13)$ & $8(5-12)$ & 0.004 \\
\hline Follow-up (months) & $40.3(19.5-53.1)$ & $40.9(24.7-53.8)$ & $39.4(17.0-52.4)$ & $40.6(17.1-57.0)$ & 0.502 \\
\hline \multicolumn{6}{|l|}{ Surgery $(\%)$} \\
\hline Open & $284(56 \%)$ & $123(53 \%)$ & $145(59 \%)$ & $16(55 \%)$ & \multirow[t]{3}{*}{0.251} \\
\hline Laparoscopic & $195(39 \%)$ & $99(43 \%)$ & $88(36 \%)$ & $8(28 \%)$ & \\
\hline Missing & $25(5 \%)$ & $8(3 \%)$ & $12(5 \%)$ & $5(17 \%)$ & \\
\hline \multicolumn{6}{|l|}{ PSA nadir $<0.2 \mathrm{ng} / \mathrm{ml}(\%)$} \\
\hline Yes & $461(91 \%)$ & $213(93 \%)$ & $221(90 \%)$ & $27(93 \%)$ & \multirow[t]{3}{*}{0.853} \\
\hline No & $36(7 \%)$ & $15(7 \%)$ & $19(8 \%)$ & $2(7 \%)$ & \\
\hline Missing & $7(1 \%)$ & $2(1 \%)$ & $5(2 \%)$ & 0 & \\
\hline \multicolumn{6}{|l|}{ Biochemical recurrence $(\%)$} \\
\hline Yes $^{\mathrm{b}}$ & $142(28 \%)$ & $65(28 \%)$ & $70(29 \%)$ & $7(24 \%)$ & \multirow[t]{3}{*}{0.874} \\
\hline No & $351(70 \%)$ & $163(71 \%)$ & $167(68 \%)$ & $21(72 \%)$ & \\
\hline Missing & $11(2 \%)$ & $2(1 \%)$ & $8(3 \%)$ & $1(3 \%)$ & \\
\hline \multicolumn{6}{|l|}{ Gleason score RP (\%) } \\
\hline$<7$ & $348(69 \%)$ & $165(72 \%)$ & $162(66 \%)$ & $21(72 \%)$ & \multirow[t]{4}{*}{0.148} \\
\hline 7 & $111(22 \%)$ & $44(19 \%)$ & $60(24 \%)$ & $7(24 \%)$ & \\
\hline$>7$ & $30(6 \%)$ & $10(4 \%)$ & $20(8 \%)$ & 0 & \\
\hline Missing & $15(3 \%)$ & $11(5 \%)$ & $3(1 \%)$ & $1(3 \%)$ & \\
\hline \multicolumn{6}{|l|}{ Pathological stage (pTNM) $(\%)$} \\
\hline pT2 & $349(69 \%)$ & $170(74 \%)$ & $165(67 \%)$ & $14(48 \%)$ & \multirow[t]{3}{*}{0.017} \\
\hline pT3 or pT4 & $143(28 \%)$ & $54(23 \%)$ & $76(31 \%)$ & $13(45 \%)$ & \\
\hline Missing & $12(2 \%)$ & $6(3 \%)$ & $4(2 \%)$ & $2(7 \%)$ & \\
\hline \multicolumn{6}{|l|}{ Surgical margins (\%) } \\
\hline Positive & $211(42 \%)$ & $93(40 \%)$ & $102(42 \%)$ & $16(55 \%)$ & \multirow[t]{3}{*}{0.341} \\
\hline Negative & $270(54 \%)$ & $125(54 \%)$ & $133(54 \%)$ & $12(41 \%)$ & \\
\hline Missing & $23(5 \%)$ & $12(5 \%)$ & $10(4 \%)$ & $1(3 \%)$ & \\
\hline \multicolumn{6}{|l|}{ Extracapsular extension $(\%)$} \\
\hline Yes & $175(35 \%)$ & $72(31 \%)$ & $89(36 \%)$ & $14(48 \%)$ & \multirow[t]{3}{*}{0.204} \\
\hline No & $221(44 \%)$ & $102(44 \%)$ & $110(45 \%)$ & $9(31 \%)$ & \\
\hline Missing & $108(21 \%)$ & $56(24 \%)$ & $46(19 \%)$ & $6(21 \%)$ & \\
\hline \multicolumn{6}{|l|}{ Invasion seminal vesicles (\%) } \\
\hline Yes & $45(9 \%)$ & $15(7 \%)$ & $25(10 \%)$ & $5(17 \%)$ & \multirow[t]{3}{*}{0.068} \\
\hline No & $446(88 \%)$ & $211(92 \%)$ & $214(87 \%)$ & $21(72 \%)$ & \\
\hline Missing & $13(3 \%)$ & $4(2 \%)$ & $6(2 \%)$ & $3(10 \%)$ & \\
\hline Lymph node dissection (\%) & $230(46 \%)$ & $83(36 \%)$ & $131(53 \%)$ & $16(55 \%)$ & 0.001 \\
\hline Positive lymph nodes (\%) & $17(3 \%)$ & $6(3 \%)$ & $9(4 \%)$ & $2(7 \%)$ & 0.726 \\
\hline
\end{tabular}

Data presented as median (IQR) or numbers (\%)

$B M I$ body mass index, $P S A$ prostate specific antigen, $p T N M$ pathological tumor-node-metastasis, $R P$ radical prostatectomy

${ }^{\text {a }}$ Missing $n=5$

b Including 36 patients who did not reach post-operative PSA levels $<0.2 \mathrm{ng} / \mathrm{ml}$ 


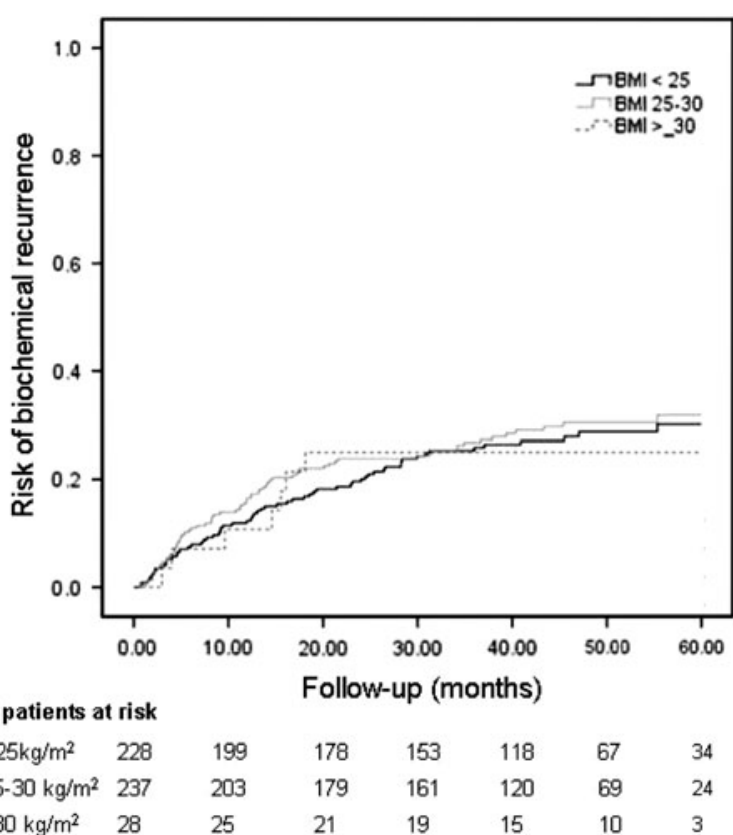

Fig. 1 The 5-year risk of biochemical recurrence in normal weight, overweight, and obese prostate cancer patients treated with radical prostatectomy $(n=493)$. Log rank $P=0.810)$

surgical margins were all statistically significant predictors of risk of BCR after RP.

\section{Discussion and conclusion}

In the present study among Dutch men diagnosed with PC, BMI was weakly associated with higher pathological tumor (pT) stage and higher prediagnostic PSA levels in patients treated with RP. Gleason score, pathological stage, and positive surgical margins were independent predictors of BCR, whereas BMI did not add any prognostic value in multivariable proportional hazards regression analyses.

Our findings are consistent with other European studies which did not find a prognostic effect of BMI in patients treated with RP [5, 8]. Only one study reported a trend toward statistical significance for BMI as independent prognostic factor for BCR [7]. Addition of BMI to a multivariable model, however, did not significantly increase predictive accuracy [7]. Whereas most European studies so far were not able to find an association between BMI and any clinical or pathological characteristics, several studies from the United States did report BMI as predictor of BCR and adverse pathological findings after RP [13-15]. These inconsistent results might be explained by the lower rates of obesity and severe obesity in Europe compared to the United States [1, 2].

A remarkable observation in this study is the weak positive association between BMI and prediagnostic PSA levels among RP patients, which was not observed in the overall study population. Several studies observed an inverse association between BMI and prediagnostic PSA levels [16, 17]. Based on the theory of hemodilution, it has been hypothesized that obese patients have larger plasma or serum volumes, which may lead to lower PSA concentrations [16]. It has also been suggested that lower PSA levels in obese patients might result from decreased androgenic activity [18]. Our results indicated a weak correlation between BMI and PSA levels and were limited to a small subpopulation of patients treated with RP; therefore, we cannot rule out that our result was a chance finding.

Another finding of our study was the association between BMI and pathological tumor (pT) stage among RP patients, suggesting that advanced-staged tumors were more common among obese patients. As reviewed by others, obesity might indeed play a role in PC aggressiveness, i.e. high stage, high grade, and increased risk of recurrence or mortality [19]. It has been hypothesized that both nonbiological and biological mechanisms can be responsible for the association between tumor aggressiveness and body size. Firstly, it might be more difficult to detect (early) PC in obese men, due to lower PSA levels [16, 17] and difficult digital rectal examinations [19]. Secondly, difficulties related to treatment might be responsible for an aggressive type of PC in obese men. Pathological findings related to technical aspects of surgery like positive surgical margins, however, would be more likely to be affected than tumor grade or stage. Finally, alterations in levels of steroid hormones, adipokines, and inflammatory mediators might also drive PC toward a more aggressive form in obese men $[19,20]$.

Evidence is growing that differentiation between total adiposity and distribution of adipose tissue is relevant in the studies related to obesity and PC. Recent studies suggested that measures of body fat distribution might be better predictors of PC risk and prognosis when compared to BMI [21, 22]. Fat distribution measurements usually distinct subcutaneous fat from visceral fat depots or simply indicate the location of adipose tissue. Skin fold measurements, waist circumference, and waist-to-hip ratios are frequently used estimates for the amount and location of adipose tissue. Magnetic resonance imaging (MRI) and computed tomography (CT) are considered more reliable methods for assessing subcutaneous and visceral fat content [23]. Von Hafe et al. [22] examined the relation between abdominal visceral fat accumulation, as measured by $\mathrm{CT}$, and PC incidence within a case-control study. They found that visceral fat area and visceral to subcutaneous fat ratio were strongly associated with increased PC risk (crude OR 4.6, 95\% CI: 2.6-8.2 and OR 6.0, 95\% CI: 2.3-11.0, respectively). Unfortunately, we did not have data on any measures of fat distribution. Other potential limitations of our study might 
Table 3 Univariable and multivariable proportional hazards regression models predicting biochemical recurrence after radical prostatectomy (RP)

\begin{tabular}{|c|c|c|c|c|c|c|c|}
\hline & \multirow[t]{2}{*}{$n$} & \multicolumn{3}{|c|}{ Univariable } & \multicolumn{3}{|c|}{ Multivariable $(n=444)^{\mathrm{a}, \mathrm{b}}$} \\
\hline & & HR & $95 \% \mathrm{CI}$ & $P$ values & Adjusted HR & $95 \% \mathrm{CI}$ & $P$ values \\
\hline $\operatorname{BMI}\left(\mathrm{kg} / \mathrm{m}^{2}\right)$ & 493 & 1.02 & $0.97-1.07$ & 0.525 & 0.99 & $0.93-1.06$ & 0.732 \\
\hline BMI & 493 & & & & & & \\
\hline$<25 \mathrm{~kg} / \mathrm{m}^{2}$ & & 1.00 & - & - & & & \\
\hline $25-30 \mathrm{~kg} / \mathrm{m}^{2}$ & & 1.08 & $0.77-1.51$ & 0.658 & & & \\
\hline$\geq 30 \mathrm{~kg} / \mathrm{m}^{2}$ & & 0.90 & $0.41-1.96$ & 0.789 & & & \\
\hline Age at RP (years) & 493 & 1.05 & $1.02-1.08$ & 0.003 & 1.02 & $0.98-1.05$ & 0.396 \\
\hline Surgery & 472 & & & & & & \\
\hline Open & & 1.00 & - & - & & & \\
\hline Laparoscopic & & 1.15 & $0.81-1.62$ & 0.429 & & & \\
\hline Year of RP & 493 & 1.07 & $0.90-1.27$ & 0.441 & & & \\
\hline Prediagnostic PSA level (ng/ml) & 489 & 1.03 & $1.01-1.05$ & 0.002 & 1.00 & $0.98-1.02$ & 0.866 \\
\hline Prediagnostic PSA level & 489 & & & & & & \\
\hline$<4 \mathrm{ng} / \mathrm{ml}$ & & 1.00 & - & - & & & \\
\hline $4-10 \mathrm{ng} / \mathrm{ml}$ & & 3.02 & $0.95-9.58$ & 0.061 & & & \\
\hline$\geq 10 \mathrm{ng} / \mathrm{ml}$ & & 4.99 & $1.57-15.89$ & 0.006 & & & \\
\hline Gleason score at RP & 478 & & & & & & \\
\hline$<7$ & & 1.00 & - & - & 1.00 & - & - \\
\hline 7 & & 2.55 & $1.77-3.68$ & $<0.001$ & 1.71 & $1.13-2.60$ & 0.012 \\
\hline$>7$ & & 4.39 & $2.64-7.31$ & $<0.001$ & 2.55 & $1.43-4.52$ & 0.001 \\
\hline Pathological stage (pTNM) & 483 & & & & & & \\
\hline pT2 & & 1.00 & - & - & 1.00 & 1.00 & - \\
\hline $\mathrm{pT} 3$ or $\mathrm{pT} 4$ & & 2.50 & $1.79-3.50$ & $<0.001$ & 1.68 & $1.13-2.49$ & 0.010 \\
\hline Extracapsular extension & 386 & 2.41 & $1.62-3.58$ & $<0.001$ & & & \\
\hline Positive surgical margins & 470 & 4.33 & $2.94-6.38$ & $<0.001$ & 2.85 & $1.87-4.35$ & $<0.001$ \\
\hline Invasion seminal vesicles & 480 & 2.58 & $1.64-4.04$ & $<0.001$ & & & \\
\hline Positive lymph nodes ${ }^{\mathrm{c}}$ & 489 & 2.93 & $1.54-5.58$ & 0.001 & 1.57 & $0.80-3.07$ & 0.186 \\
\hline
\end{tabular}

$B M I$ body mass index, $P S A$ prostate specific antigen, $p T N M$ pathological tumor-node-metastasis, $R P$ radical prostatectomy

${ }^{\text {a }}$ Variables in the multivariable model are adjusted for each other

${ }^{\mathrm{b}}$ Replacing pathological stage by extracapsular extension and seminal vesicles invasion in the multivariable model resulted in adjusted hazards ratios $(95 \% \mathrm{CI})$ of $1.45(0.92-2.28, P=0.106)$ for extracapsular extension and $1.06(0.59-1.91, P=0.845)$ for seminal vesicles invasion, while the adjusted hazards ratios for the remaining variables hardly changed

c The reference category is: no lymph node dissection performed or no positive lymph nodes

be its retrospective data collection, self-reported BMI, relatively short follow-up (median 40.3 months), and small number of patients, especially in the obese group. Results therefore need to be interpreted with some caution. We cannot exclude the possibility that the relatively large number of missing values for BMI might have been a source of selection bias, although the observation that patients with missing BMI did not have more advanced tumor characteristics compared to the patients with evaluable BMI in our RP cohort (data not shown) argues against this. The absence of an association between BMI and BCR might also be explained by treatment-related selection. If obese patients tend to have more advanced tumor characteristics at diagnosis, and therefore have other types of treatment (e.g. ADT), while mainly normal weight, low-risk patients will have surgery, a possible association between BMI and BCR could be missed. Our aim was, however, to study the association between BMI and BCR in an average population-based RP cohort. We conclude from our results that in this cohort, BMI does not have any prognostic value for risk of BCR. Whether BMI is associated with risk of recurrence in other treatment groups should be verified in the future studies.

In summary, BMI did not affect clinical or pathological characteristics of PC patients at time of diagnosis. Compared with non-obese men, pathological stage tended to be higher in obese men treated with RP. Clinical relevance of these findings with respect to risk of BCR, however, needs 
to be further elucidated, since BMI itself was not an independent predictor of BCR after RP.

Acknowledgments D.E.G. Kok is supported by a research grant from the World Cancer Research Fund (WCRF-NL and WCRF-UK). This project was funded in part by contract number 018827 (Polygene) from the 6th Framework Program of the European Union.

Conflict of interest The authors declare that they have no conflict of interest.

Open Access This article is distributed under the terms of the Creative Commons Attribution Noncommercial License which permits any noncommercial use, distribution, and reproduction in any medium, provided the original author(s) and source are credited.

\section{References}

1. Ogden CL, Carroll MD, Curtin LR, McDowell MA, Tabak CJ, Flegal KM (2006) Prevalence of overweight and obesity in the united states, 1999-2004. Jama 295(13):1549-1555

2. Branca F, Nikogosian H, Lobstein T (eds) (2007) The challenge of obesity in the who European region and the strategies for response. World health organization

3. Isbarn H, Jeldres C, Budaus L, Salomon G, Schlomm T, Steuber T, Chun FK, Ahyai S, Capitanio U, Haese A, Heinzer H, Huland H, Graefen M, Karakiewicz P (2009) Effect of body mass index on histopathologic parameters: results of large European contemporary consecutive open radical prostatectomy series. Urology 73(3):615-619

4. Paaskesen CE, Borre M (2008) Body mass index and prognostic markers at radical prostatectomy. Scand $\mathbf{J}$ Urol Nephrol 42(3):230-236

5. Pfitzenmaier J, Pritsch M, Haferkamp A, Jakobi H, Fritsch F, Gilfrich C, Djakovic N, Buse S, Pahernik S, Hohenfellner M (2009) Is the body mass index a predictor of adverse outcome in prostate cancer after radical prostatectomy in a mid-european study population? BJU Int 103(7):877-882

6. Gallina A, Karakiewicz PI, Hutterer GC, Chun FK, Briganti A, Walz J, Antebi E, Shariat SF, Suardi N, Graefen M, Erbersdobler A, Salonia A, Rigatti P, Huland H, Montorsi F (2007) Obesity does not predispose to more aggressive prostate cancer either at biopsy or radical prostatectomy in European men. Int $\mathbf{J}$ Cancer 121(4):791-795

7. Chun FK, Briganti A, Graefen M, Erbersdobler A, Walz J, Schlomm T, Meschke M, Haese A, Valiquette L, Huland H, Karakiewicz PI (2007) Body mass index does not improve the ability to predict biochemical recurrence after radical prostatectomy. Eur J Cancer 43(2):375-382

8. van Roermund JG, Kok DE, Wildhagen MF, Kiemeney LA, Struik F, Sloot S, van Oort IM, Hulsbergen-van de Kaa CA, van Leenders GJ, Bangma CH, Witjes JA (2009) Body mass index as a prognostic marker for biochemical recurrence in Dutch men treated with radical prostatectomy. BJU Int 104(3):321-325

9. van Roermund JG, Hinnen KA, Battermann JJ, Witjes JA, Bosch JL, Kiemeney LA, van Vulpen M (2010) Body mass index is not a prognostic marker for prostate-specific antigen failure and survival in Dutch men treated with brachytherapy. BJU Int 105(1):42-48

10. Gudmundsson J, Sulem P, Manolescu A, Amundadottir LT, Gudbjartsson D, Helgason A, Rafnar T, Bergthorsson JT,
Agnarsson BA, Baker A, Sigurdsson A, Benediktsdottir KR, Jakobsdottir M, Xu J, Blondal T, Kostic J, Sun J, Ghosh S, Stacey SN, Mouy M, Saemundsdottir J, Backman VM, Kristjansson K, Tres A, Partin AW, Albers-Akkers MT, Godino-Ivan Marcos J, Walsh PC, Swinkels DW, Navarrete S, Isaacs SD, Aben KK, Graif T, Cashy J, Ruiz-Echarri M, Wiley KE, Suarez BK, Witjes JA, Frigge M, Ober C, Jonsson E, Einarsson GV, Mayordomo JI, Kiemeney LA, Isaacs WB, Catalona WJ, Barkardottir RB, Gulcher JR, Thorsteinsdottir U, Kong A, Stefansson K (2007) Genome-wide association study identifies a second prostate cancer susceptibility variant at 8q24. Nat Genet 39(5):631-637

11. Website for nation-wide guidelines on oncology and palliative care from the netherlands. Parts are also available in English. www.oncoline.nl

12. Greene FL, Page DL, Fleming ID et al (2002) Ajcc cancer staging manual, 6th edn. Springer-verlag, New york

13. Amling CL, Riffenburgh RH, Sun L, Moul JW, Lance RS, Kusuda L, Sexton WJ, Soderdahl DW, Donahue TF, Foley JP, Chung AK, McLeod DG (2004) Pathologic variables and recurrence rates as related to obesity and race in men with prostate cancer undergoing radical prostatectomy. J Clin Oncol 22(3):439-445

14. Bassett WW, Cooperberg MR, Sadetsky N, Silva S, DuChane J, Pasta DJ, Chan JM, Anast JW, Carroll PR, Kane CJ (2005) Impact of obesity on prostate cancer recurrence after radical prostatectomy: data from capsure. Urology 66(5):1060-1065

15. Freedland SJ, Banez LL, Sun LL, Fitzsimons NJ, Moul JW (2009) Obese men have higher-grade and larger tumors: an analysis of the duke prostate center database. Prostate Cancer Prostatic Dis 12(3):259-263

16. Banez LL, Hamilton RJ, Partin AW, Vollmer RT, Sun L, Rodriguez C, Wang Y, Terris MK, Aronson WJ, Presti JC Jr, Kane CJ, Amling CL, Moul JW, Freedland SJ (2007) Obesity-related plasma hemodilution and psa concentration among men with prostate cancer. Jama 298(19):2275-2280

17. Beebe-Dimmer JL, Faerber GJ, Morgenstern H, Werny D, Wojno K, Halstead-Nussloch B, Cooney KA (2008) Body composition and serum prostate-specific antigen: review and findings from flint men's health study. Urology 71(4):554-560

18. Freedland SJ, Platz EA, Presti JC Jr, Aronson WJ, Amling CL, Kane CJ, Terris MK (2006) Obesity, serum prostate specific antigen and prostate size: implications for prostate cancer detection. J Urol 175(2):500-504 discussion 504

19. Freedland SJ, Platz EA (2007) Obesity and prostate cancer: making sense out of apparently conflicting data. Epidemiol Rev 29:8897

20. Mistry T, Digby JE, Desai KM, Randeva HS (2007) Obesity and prostate cancer: a role for adipokines. Eur Urol 52(1):46-53

21. Pischon T, Boeing H, Weikert S, Allen N, Key T, Johnsen NF, Tjonneland A, Severinsen MT, Overvad K, Rohrmann S, Kaaks R, Trichopoulou A, Zoi G, Trichopoulos D, Pala V, Palli D, Tumino R, Sacerdote C, Bueno-de-Mesquita HB, May A, Manjer J, Wallstrom P, Stattin P, Hallmans G, Buckland G, Larranaga N, Chirlaque MD, Martinez C, Redondo Cornejo ML, Ardanaz E, Bingham S, Khaw KT, Rinaldi S, Slimani N, Jenab M, Riboli E (2008) Body size and risk of prostate cancer in the European prospective investigation into cancer and nutrition. Cancer Epidemiol Biomarkers Prev 17(11):3252-3261

22. von Hafe P, Pina F, Perez A, Tavares M, Barros H (2004) Visceral fat accumulation as a risk factor for prostate cancer. Obes Res 12(12):1930-1935

23. van der Kooy K, Seidell JC (1993) Techniques for the measurement of visceral fat: a practical guide. Int J Obes Relat Metab Disord 17(4):187-196 